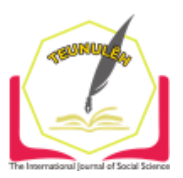

Jurnal Ilmiah Teunuleh

The International Journal of Social Sciences

Vol. 2, Issue. 2, June 2021

E-ISSN: $2746-4393$

\title{
PORTFOLIO ASSESSMENT OF TPACK APPROACH-BASED MATHEMATICS SUBJECTS IN PRIMARY SCHOOLS
}

\author{
Sri Gianti ${ }^{1}$ \\ Universitas Lampung, Indonesia \\ srigianti18@gmail.com \\ Rochmiyati $^{2}$ \\ rochmiyatiazwardi@yahoo.co.id \\ Nurhanurawati ${ }^{3}$ \\ nurhanurawati94@gmail.com
}

\begin{abstract}
Assessing students' knowledge and success during and after learning and teaching is an ingrained part of education because it offers the most important specifics for teachers. This action research aims to determine the influence of portfolio assessment in TPACKbased mathematics subjects. The two methods used include student portfolio attitude surveys and teacher surveys. It found that most students had a clear understanding of how portfolios were created and recognized that portfolios could help them in learning maths better in many aspects. Likewise, most teachers consider portfolios practical especially in pointing out student problems and monitoring their learning progress.
\end{abstract}

Keywords: Portfolio Assessment, Mathematics, TPACK.

\section{A. Introduction}

Portfolio assessment is in line with the 2013 curriculum that prioritizes the learning process to be assessed, so that assessment can be achieved in the face of affective, cognitive, and psychomotor. According to Atmaja (2016, p. 150) portfolio Assessment is an assessment of student performance. This assessment wants to measure the extent to which students' knowledge is internalized into a work that isdocumented. According to Adisusila (2014, p. 249) "Portfolios are a collection of well-documented and regular student work. This student's work can be clippings, individual assignments, interview results and others". In the implementation of the assessment, teachers, in addition to 
providing final scores, should also provide descriptive information records related to some achievements and negative records made by students. (ministries of primary and secondary education, 2016, p. 14). In the opinion of (Budimansyah, 2003, p. 9), "Portfolio-based learning model is based on the thinking of four pillars of education consisting of (1) learningto know, (2) learningto do, (3) learning to be, and (4) learning to live together. Calls this kind of self-assessment (spontaneous and implicit) selfcontrol (Hadji, 2001). Clarifis that self-control or cognitive regulation, when mediated by awareness, allows the transition to a metacognitive (conscious and reflxive) (Villas Boas, 2008).

According to Cole, Ryan and Kick were quoted by Wahyudi (2010, pp. 288-298) the portfolio is divided into two namely process portfolio and portolio product. The process portfolio shows the stages of learning and presents a record of the progress of learners over time. Product portfolio is a form of portfolio assessment that only emphasizes the mastery of materials from tasks required in competency standards, basic competencies and indicators of achievement of learning outcomes and only shows the best documents (evidence).

In response to requirements for reformed assessment, alternative assessment methods have come into play. Thus, alternative assessment methods should be used instead of traditional assessment for providing every student with the best learning opportunity "If we truly SSbelieve in inclusion and diversity, which builds on the understanding that everyone is capable of learning and worthy of the best possible investment in his or her education, it becomes unsustainable to continue using an assessment model that has traditionally developed to focus on selection, certification and accountability" (Buhagiar, 2007). According to Kusaeri (2014,p. 127), "Portfolio assessment is applied to achieve the objectives consisting of: (1) teachers or lecturers can know the development experienced by students / students, (2) teachers / lecturers document the ongoing learning process, (3) the work performance of students / learners can be noticed or get more attention by teachers or lecturers well, (4) the effectiveness of the learning process can be improved, exchange information with parents / guardians of learners and accelerate the growth of positive self-concept of students or learners. In classroom assessment, the portfolio can be used to achieve several objectives, including: a) Appreciating the progress experienced by students, b) Documenting the ongoing learning process, c) Paying attention to the best work performance of students, d) Reflecting on the ability to take risks and conduct experimentation, e) Improving the 
effectiveness of the teaching process, f) Exchanging information with parents /guardians and other teachers, e) Fostering and accelerating the growth of positive self-concepts in students, h) Improving the ability to conduct self-reflection, i) Assisting students in formulating goals. (Realin Setiamihardja).

The learning process is the main component that must be established in the teaching process that serves as an indicator of educational success (Dewi, 2018). Learning that needs to be developed and is expected to improve the competence of students, especially in the content of mathematical materials. As Auliya (2016) argues, mathematics is considered a difficult lesson because of its abstract, logical, systematic, and confusing mathematical characteristics. This focus on assessment helps educators with the development of mathematics instruction and allows for more holistic measurement. Using alternative assessment methods provides a more comprehensive picture and more authentic information abaout leamers "knowledge, skills, attitudes, and competences which are developed during the teaching process (Letina, 2015). The proper implementation of an assessment instrument must necessarily be followed by an evaluation. (Feni Kurnia, Dadan Rosana, Supahar, 2017). As in other disciplines, assessment in math is the primary factor in determining what students understand, as well as what and how they are learning (Hemje, 2014); whether or not they have accomplished the learning goals (Hanifa, 2017). Moreover, it provides teachers with insight into the success of teaching strategies and students preference of learning styles (Damon,, 2017).

According to (Rusman Deni Kurniawan, Cepi Rivana, 2011) entering the century of Technology and Communication (ICT) is now very felt the need and importance for improvement and improvement of the quality of learning. Web-based learning is a learning activity that utilizes the media site (website) that can be accessed through the internet network. TPACK is a framework of technology integration, pedagogy, which identifies the three types of knowledge needed to be combined to develop a learning model for the success of achieving modern learning objectives (Chairil Faif Pasani, 2018). TPACK is one of the alternative frameworks for developing learning models in the classrooms during the COVID-19 pandemic. With this TPACK framework, teachers are expected to use technology as a medium of assistance in facilities for students to understand a learning content, especially for mathematical content that is abstract and of course still consider pedagogical aspects. Doering, Veletsianos, Scharber, \&Miller (2009) in his research stated that TPACK's evangelism is able to increase confidence as 
well as improve the competence of content, pedagogical and technology teachers in designing learning.

Test results will be used as one of the main basis for referring to a process or action. If the assessment process is less able to assess the results of a study that can actually lead to the maximum of subsequent activities. Therefore, assessment becomes essential in a learning process including assessment in schools. The implementation of this study is intended to determine the influence of portfolio assessment techniques of mathematics subjects based on TPACK approach in elementary schools.

\section{B. Method}

The population of this study is teachers and students of grade $V$ at SD Negeri in the RA cluster. Kartini is located in the North Kotabumi District of North Lampung Regency. The time of implementation of research in the even semester of the 2020/2021 school year. This research is qualitative descriptive research. The research method used is the library study method which is a study of literature and journals. Where the results of the research which is data from the study are grouped into three namely: Class learning results taught using performance assessment in Mathematics Learning, Learning outcomes in the classroom taught using Portfolio assessment, learning achievements and In the classroom taught using the TPACK approach. Design research is Posttest Only Control Design.

The research instruments used in this study included a portfolio of students using attitude surveys, adapted from Caner (2010), consisting of 12 statements that students scored on a five-point scale, ranging from 'strongly agreed' to 'strongly disagree'. The statement covers three areas: awareness, real practice, and attitude. Another research tool used was the teacher survey, adapted from Arter and Spandel (1992), consisting of seven questions with the aim of using a portfolio; its advantages, disadvantages and effectiveness; how teachers handle portfolios in their classrooms and encourage their students to reflect on their work; the problems they face; and the assessment methods they like.

\section{Finding and Discussion}

From the findings, it was found that most of the participants $(M=4.45)$, who had a clear idea of how to structure the portfolio, agreed that it was helpful in learning and assessment, in improving writing skills, organizing, presenting, reflecting. in learning, and 
showing exactly their advantages and disadvantages. According to Davis (2005), creating portfolios provides specific teachers with the importance of diagnosing students' strengths and weaknesses to support and improve their learning performance. However, about half of students $(M=2.77)$ consider portfolios to be an increased burden, and only slightly less than half $(M=2.35)$ say they actually prefer to be evaluated using portfolios. Given the extra responsibilities that come with portfolios, it seems that many students find completing a portfolio too much and a bit difficult. Indeed, portfolio assessment is considered time-consuming enough for students to complete as well as for teachers to take partespecially if theportfolio is conducted in addition to traditional classroom assignments and evaluations (Gómez, 1999).

As for teachers, they all report using portfolios to demonstrate processes other than products, monitor student progress, identify problems and help them determine outcomes when portfolios are given a percentage of overall grades at the end of the semester. However, the obstacles they face include a lack of student commitment, readiness to make good use of their portfolios, time-consuming use of portfolios, and the use of portfolios that are not taken seriously by their majors. The criteria teachers use to evaluate portfolios are quality, growth, depth of reflection and completeness. Most teachers agree that the use of portfolios for assessment is more objective and comprehensive than a one-off test, provided that reflection is included. This is in line with Baume's statement (2000) that the portfolio isa very practical metode to influence, support, integrate andevaluate the work ofstudents. Positive results from the student survey support Caner's findings (2010). The lack of frequent neutral and negative responses can be attributed to students' lack of familiarity with tools and partly to their past learning experiences, which do not encourage self-learning. Students' self-learning skills can be developed through active portfolio keeping activities (Huang, 2012). Karena it, it is advisable to train students about the skills necessary to utilize the portfolio properly. These include critical thinking, time management, organization and above all metacognition.

Serhani (2007) explained that students with mentoring and teacher guidance are actually instinctively equipped with soft skills when putting together their own portfolios. This is help students gain a sense of responsibility for their work. Findings from the teacher survey demonstrate teachers' confidence in the effectiveness of portfolios in teaching and learning and their assessment and willingness to use it. However, they should also be aware of the need to use a variety of assessment forms that can measure 
new learning outcomes and get used to the specific features and requirements of a welldeveloped portfolio. In addition, it is about the administration having to be more willing to accept and support any changes in the assessment method and invest time and effort in teacher training.

\section{Conclusion}

Responses from students in this study revealed that they realized the advantages of collecting portfolios in math learning. Nevertheless, they believe that portfolio valuations come with additional burdens and tasks. Thus, students should be informed in advance of their positive and negative attributes. In addition, students should be directed to apply tactics or self-learning techniques that can help them recognize the steps of portfolio preparation. This is because different student learning styles become one of the factors in the utilization of portfolios into the teaching and learning process. Incorporating portfolios into student learning and assessment processes requires careful arrangement. To embed the portfolio into TPACK-based mathematics learning, teachers should familiarize students with the idea of self-learning. Equally important is that teachers should explicitly discuss with pro students actualizing the portfolio both as a learning tool and as an optional assessment instrument. With the successful use of portfolio assessments, it is likely that teachers and students can engage with each other in TPACK-based math teaching and learning.

\section{Bibliography}

Agusditya, P. H., Sri Asri, I. G. A. A., \& Suara, I. M. (2017). The Effect of Scientific Approach Based on Portfolio Assessment towards the Learning Outcomes of Civic Education of the Students Grade V Viewed from the Tendency of Observing Objects on Theme 7 SDN 4 Ubung. Journal of Education Research and Evaluation, 1(2). doi:10.23887/jere.v1i2.9842

Da Silva, N. C., \& Loos-Sant'Ana, H. (2017). Developing psychic self-regulation in children through self-assessment portfolios in school interaction. Paideia, 27. doi:10.1590/1982-432727s1201713

Dewi, D. A. P. H. (2018). Pengaruh Pendekatan Contextual Teaching And Learning Berbasis Penilaian Portofolio Terhadap Kompetensi Pengetahuan IPA. Journal for Lesson and Learning Studies, 1(3), 237-242.

Fadillah, A., Slamet, A., \& Haryani, S. (2019). Teacher Problematics in Applying Authentic Assessment in Curriculum 2013 of Class IV State Elementary School in Serang Subdistrict. Journal of Primary Education, 8(5).

Gozuyesil, Eda; Tanriseven, I. (2017). A Meta-Analysis of the Effectiveness of Alternative 
Portfolio Assessment of TPACK Approach-Based Mathematics Subject in...

Assessment Techniques. Eurasian Journal of Educational Research, 70, 37-56.

Korkmaz, S. (2017). The common European framework and the European language portfolio: Involving learners' judgments in the assessment process. Turkish Online Journal of Educational Technology, 2017(December Special Issue INTE).

Kuntarto, E., \& Gustina, R. (2019). Pelaksanaan Penilaian Portofolio di Sekolah Dasar. Jurnal Gentala Pendidikan Dasar, 4(2). doi:10.22437/gentala.v4i2.8437

Mehmet, D., Cynthia, A. T., \& Uğur, B. (2018). Comparative investigation of alternative assessment methods used in Turkey and United States elementary 4th grade mathematics curriculum. International Journal of Educational Administration and Policy Studies, 10(7). doi:10.5897/ijeaps2018.0561

Munajib, M., Sutrisno, S., \& Kamid, K. (2021). Studi Eksploratif Tentang Pemahaman Guru Terhadap Kerangka Kerja TPACK Dalam Pembelajaran Matematika di Tengah Pandemi di SMA Kota Jambi. Jurnal Cendekia : Jurnal Pendidikan Matematika, 5(1 SE-Articles). doi:10.31004/cendekia.v5i1.451

Nisrina, Israwat, \& Yusuf, M. N. (2018). Kendala Guru Dalam Melaksanakan Penilaian Portofolio Pada Kurikulum 2013 Di Sekolah Dasar Negeri 69 Banda Aceh. Jurnal IImiah Mahasiswa PENDIDIKAN GURU SEKOLAH DASAR (PGSD), 3(3), 42-45.

Ohashi, Y. (2018). Innovation and the Assessment of Elementary School English in Japan : Issues and Concerns. Fukuoka Jo Gakuin Institutional Repository, 4.

Paz-Albo Prieto, J., Herranz Llácer, C. V., \& Hervás Escobar, A. (2017). THE EFFECT OF PORTFOLIOS ON HIGHER EDUCATION STUDENTS LEARNING. INTED2017 Proceedings, 1. doi:10.21125/inted.2017.1491

Phothongsunan, S. (2020). Student and teacher engagement in Learning and assessment with portfolios. Cypriot Journal of Educational Sciences, 15(6). doi:10.18844/CJES.V1516.5317

Poerwanti, J. I. S., \& Winarni, R. (2021). Pelatihan Dan Pendanpingan Merancang linstrumen Assement For Learning Bebasis Fortofolio Pada Guru-Guru Sekolah. Jurnal Pengabdian Masyarakat: Widya Laksana, 10(1), 44-51.

Rafi, I., \& Sabrina, N. (2019). Pengintegrasian TPACK dalam Pembelajaran Geometri SMA untuk Mengembangkan Profesionalitas Guru Matematika. SJME (Supremum Journal of Mathematics Education), 3(1). doi:10.31235/osf.io/v2ygb

Taufina, T., \& Chandra, C. (2017). The Implication of Authentic Assessment in Thematic Integrated Learning Process at Lower Level Elementary School Early Childhood Development BT - Proceedings of the International Conference of Early Childhood Education (ICECE 2017). 140-143. doi:10.2991/icece-17.2018.36

Tilaar, A. L. F. (2019). The Influence of the Application of Mathematics Learning Performance Assessment and Portfolio Assessment toward Senior Highschool Students' Mathematics Achievement. International Journal of Innovative Science and Research Technology (IJISRT), 4(2), 457-466. 